\title{
Grenvillian thermal event and remnant charnockite: Isotopic evidence from the Chilka Lake granulite-migmatite suite in the Eastern Ghats belt, India
}

\author{
S Bhattacharya ${ }^{1}$, M P Deomurari ${ }^{2}$ and W Teixeira ${ }^{3}$ \\ ${ }^{1}$ Indian Statistical Institute, 203 B.T.Road, Calcutta 700 035, India. \\ e-mail:samar@isical.ac.in \\ ${ }^{2}$ Physical Research Laboratory, Ahmedabad, India. \\ ${ }^{3}$ Institute of Geosciences, Sao Paulo University, Brazil.
}

\begin{abstract}
Spectacular exposures of granulite-migmatite occur in the Chilka Lake area of the Eastern Ghats belt. The garnetiferous granite gneiss of peraluminous granitic composition, often contains restitic metapelite inclusions and is demonstrably a product of biotite-dehydration melting in pelitic rocks. On the other hand, older layers and bands of charnockitic rocks frequently occur as dismembered patches within the peraluminous granite, thus imparting a measled appearance of the granite exposures.

The partial melting and emplacement of the peraluminous granite represent the Grenvillian thermal event, as evidenced by $\mathrm{Rb}-\mathrm{Sr}$ whole rock and $\mathrm{Pb}-\mathrm{Pb}$ zircon dating. On the other hand, minor patches of charnockite represent migmatized relict, as evidenced by some older zircons, in addition to those of Grenvillian age.
\end{abstract}

\section{Introduction}

The Eastern Ghats granulite belt along the east coast of India is characterised by polyphase deformation and complex, multi-stage metamorphic evolution (Lal et al 1987; Kamineni and Rao 1988; Sen et al 1995; Dasgupta et al 1995; Bhattacharya 1996; Mohan et al 1997; Shaw and Arima 1998). The dominant lithological varieties are metapelitic granulites including khondalites, quartzites and calc-granulites; mafic granulites; orthopyroxene-bearing quartzofeldspathic gneisses (charnockite-enderbite); orthopyroxene-free granitoids (leptynites) and some anorthosite and alkaline complexes.

Deformation structures and field relations suggest structural breaks marked by cross-cutting and often transposed foliations (Rao 1976; Halden et al 1982; Bhattacharya et al 1994) and different modes of formation and/or migmatisation of charnockites
(Bhattacharya et al 1993; Bhattacharya 1996; Dobmeier and Raith 2000). Isotopic record on the granulite facies rocks of the Eastern Ghats belt is dominated by the Grenvillian thermal event (Mezger and Cosca 1999), although, Archaean, mid-Proterozoic and Pan-African dates were also reported (Vinogradov et al 1964; Paul et al 1990; Shaw et al 1997; Sarkar et al 1998; Dobmeier and Simmat 2002; Krause et al 2001). However, interpretation of these isotopic data in relation to deformation and petrologic processes have mostly been tentative. Only recently Bhattacharya et al (2001), documented a $3.0 \mathrm{Ga}$ granulite facies event defined by partial melting in basic rocks and generation of a charnockite suite in the Eastern Ghats belt.

In this article we report isotopic data on peraluminous granite (leptynite) and patchy charnockite from the Chilka Lake granulite-migmatite suite and relate the Grenvillian thermal event to biotite-dehydration melting in pelitic rocks. Also,

Keywords. Granite-migmatite; Grenvillian event; zircon population; remnant charnockite. 
the time-relation between leptynite and patchy charnockite, as evidenced by $\mathrm{Pb}-\mathrm{Pb}$ zircon dating, corroborates the hypothesis of remnant charnockite (Bhattacharya et al 1993).

\section{Geological setting}

Structural studies in several sectors have established an early dominantly compressional setting; isoclinal and rootless $F_{1}$ folds with NE-SW-trending steep axial plane foliation $S_{1}$, and common structural repetitions suggest a regional NW-SE directed compression and shortening during the development of first generation folds (Bhattacharya 1997). Also Chetty and Murthy (1998) proposed a regional tectonic framework and suggested dominant transpressional tectonics related to collisional processes.

In the Chilka Lake area of Orissa, the impress of three phases of folding and associated penetrative foliations are observed (Bhattacharya et al 1994). First generation folds, associated gneissic foliation with granulite mineral assemblage occur only as relict. Second generation folds and associated leptynitic foliation are regionally pervasive, determine the map pattern. Transposition of earlier structures and anatexis and migmatisation are dominant during the second phase of deformation. Third deformation is less intense on a regional scale, with no development of pervasive foliation. The earlier two episodes of deformation record a compressional tectonic setting while the third deformation structures, namely, fold-axis parallel stretching lineations and drag folds with axial plane parallel shear veins, indicate an extensional setting (Bhattacharya 1997).

The leptynites occur as small stock like bodies with a plattung structure, related to axial plane of second-generation folds in the pelitic granulites and pyroxene granulites (cf. figure 5 in Sen and Bhattacharya 1997). Besides the large bands, metapelites also occur as minor patches within the leptynites. In the Chilka Lake area leptynites are garnetiferous quartzofeldspathic gneisses, in terms of mineralogy and chemical composition they can be described as peraluminous granites or $s$-type granites and hence a likely product of crustal anatexis.

Patchy charnockites, which occur within leptynites also record some older structures, indicating their remnant origin (Bhattacharya et al 1993). Also, mineralogical changes, namely, increase of $K$-feldspar concentrations in the marginal parts of these patches, indicate a strong migmatisation effect from the enclosing $K$-feldspar-dominant, peraluminous granite, the leptynite (Bhattacharya et al 1994; Sen and Bhattacharya 1997). Dobmeier and Raith (2000), on the other hand, presented an alternative interpretation of the patchy charnockites of the Chilka Lake area as arrested growth.

Sen and Bhattacharya (1997) interpreted the leptynites of the Chilka area as products of micadehydration melting in pelitic and psammitic rocks. The sillimanite inclusion trails and more magnesian biotite-inclusions in some of the garnets of the leptynites are strong indicators of biotitedehydration partial melting in pelitic rocks (with sillimanite) that produced the leptynites. In the common variety of metapelites absence of prograde biotite on the one hand and occasional occurrence of quartzofeldspathic pods in them on the other, indicate melting in the neighbourhood of $850^{\circ} \mathrm{C}$. The geothermobarometric results on the common variety of metapelites indicate temperatures in the neighbourhood of $860^{\circ} \mathrm{C}$ at $8 \mathrm{kbar}$ (Sen et al 1995).

\section{Sample description}

On the basis of the petrological and geochemical investigations (Sen et al 1995; Sen and Bhattacharya 1997) we have selected six leptynite and one restitic metapelite samples for whole rock isotopic study. $\mathrm{Rb}-\mathrm{Sr}$ whole rock isotopic analyses were aimed at defining the partial melting event. Additionally, one patchy charnockite inclusion and host leptynite sample were selected for zircon analysis, to study the effects of migmatization and time relation between leptynite and patchy charnockite (figure 1).

The leptynite samples have the assemblage quartz- $K$-feldspar-plagioclase-garnet-opaque \pm sillimanite; are corundum-normative (1 to $2 \%$ ), with $\mathrm{A} / \mathrm{CNK}$ values within a narrow range (1.0 to 1.4) and $\mathrm{K}_{2} \mathrm{O} / \mathrm{Na}_{2} \mathrm{O}$ values range from 1.2 to 2.3. Lack of co-variation of $\mathrm{Sr}$ and $\mathrm{Zr}$ also suggests that very little fractionation occurred. A variety of metapelitic granulite occurs as minor patches within leptynites. These restitic patches have the assemblage garnet-cordierite-sillimanitequartz- $K$-feldspar-plagioclase; garnets in them are more magnesian $\left(X_{\mathrm{Mg}} 0.36\right)$ than those of the common metapelites $\left(X_{\mathrm{Mg}} 0.15-0.27\right)$; $\mathrm{CaO}$ (> 1\% wt.) and $\mathrm{Sr}$ (average $206 \mathrm{ppm}$ ) are also higher than those in the common metapelites $(\mathrm{CaO} \sim 0.2 \%$, $\mathrm{Sr}<50 \mathrm{ppm})$. One sample of this patchy variety (T-5/1-P4) is also analysed.

Patchy charnockite sample has the assemblage quartz- $K$-feldspar-plagioclase-orthopyroxene-ilmenite \pm garnet; contain apatite and zircon as accessory minerals. Because of their isolated occurrence within the leptynite, no meaningful results were expected in their whole rock isotopic compositions, hence only zircons from this sample were analysed. 


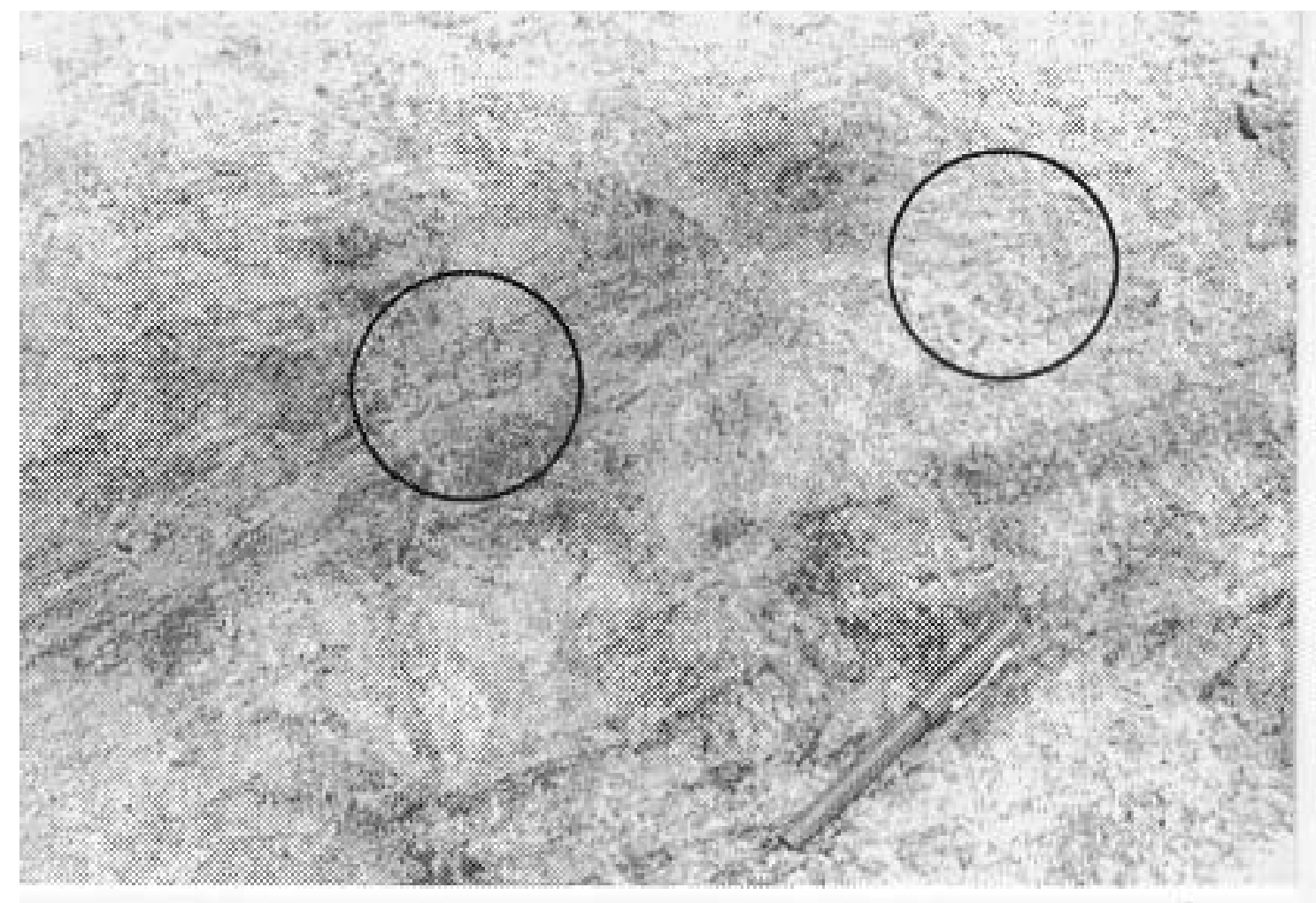

Figure 1. Field photograph showing a patchy charnockite within host leptynite. Analysed samples 10/93 (charnockite) and 11/93 (leptynite) are marked on the photograph.

Zircons from one host leptynite were also analysed in order to verify the age relation between leptynite and patchy charnockite of the area.

\section{Analytical procedure}

$\mathrm{Rb}-\mathrm{Sr}$ analysis was performed at the Geochronological Research Center (CPGeo) of the University of Sao Paulo (Brazil). The ${ }^{87} \mathrm{Sr} /{ }^{86} \mathrm{Sr}$ ratios were measured in the VG 354 multi-collector and single collector mass spectrometers, using the isotopic dilution method with absolute errors $(2 \sigma)$, and have been corrected to the mean value of NBS987 standard $[0.710254 \pm 22(2 \sigma)]$. The measured ${ }^{87} \mathrm{Sr} /{ }^{86} \mathrm{Sr}$ were normalized to ${ }^{86} \mathrm{Sr} /{ }^{88} \mathrm{Sr}$ value of 0.1194. The overall blank for the chemical procedure at the CPGeo was $4 \mathrm{ng}$ for Sr.

The in situ $\mathrm{Pb}$ isotopic analyses of zircons were carried out at the Physical Research Laboratory, Ahmedabad, India. The small ion-microprobe machine, Cameca ims 4f, used in this study is described in Goswami and Srinivasan (1994). The analytical procedure and data assessment technique, with zircon standard (sample 83407) used are described in Wiedenback and Goswami (1994). Age of the sample is computed from radiogenic ${ }^{207} \mathrm{~Pb} /{ }^{206} \mathrm{~Pb}$ ratio. Radiogenic values are computed from measured ${ }^{207} \mathrm{~Pb} /{ }^{206} \mathrm{~Pb}$ ratios after necessary common $\mathrm{Pb}$ corrections. If the correction is low $(<5 \%)$, the data are considered for age computation. Analyses belonging to the same age group constitute a population.

\section{Analytical data}

The Rb-Sr whole rock isotopic data for six granite (leptynite) and one restitic metapelite from the Chilka Lake area are presented in table 1. Six granite and one restitic metapelite inclusion define a seven point isochron age of $913 \pm 82 \mathrm{Ma}(\mathrm{MSWD}=$ 4.3) with an initial Sr ratio of $0.7405 \pm 61$ (figure 2).

The results of in situ $\mathrm{Pb}$ isotopic analysis of zircons from leptynite and patchy charnockite are presented in tables 2 and 3 . Out of five recovered zircon grains from the leptynite sample, only two are euhedral, prismatic, transparent, with inclusions of apatite and opaques. Some grains have homogeneous growth rims (figure 3a). Some other analysed zircon grains from this sample have high common $\mathrm{Pb}$ correction $(\sim 10 \%)$ and hence excluded from age computation. The two zircon grains with error ratio $\sim 1$, indicate the presence of a single zircon age population, c. $1.0 \mathrm{Ga}$ or the Grenvillian event. Nine selected zircon grains from the patchy charnockite sample, are euhedral 
Table 1. Rb-Sr isotopic data of metapelite-granitoid suite of Chilka Lake, Orissa, India.

\begin{tabular}{clcccccccc}
\hline Ref. no. & Sample no. & $\mathrm{Rb}(\mathrm{ppm})$ & Error & $\mathrm{Sr}(\mathrm{ppm})$ & Error & ${ }^{87} \mathrm{Sr} /{ }^{86} \mathrm{Sr}$ & Error $(1 \sigma)$ & ${ }^{87} \mathrm{Rb} /{ }^{86} \mathrm{Sr}$ & $\mathrm{Error}(1 \sigma)$ \\
\hline L1. & CD/2L. Gran & 176.7 & 3.5 & 125.2 & 2.5 & 0.78962 & 0.00007 & 4.118 & 0.116 \\
L2. & TA/111. Gran & 191.5 & 3.8 & 88.3 & 1.8 & 0.82332 & 0.00006 & 6.348 & 0.18 \\
L3. & HD/2L. Gran & 124.2 & 2.5 & 105.6 & 2.1 & 0.78639 & 0.0001 & 3.434 & 0.097 \\
L4. & K/10. Gran & 257.6 & 5.2 & 71.3 & 1.4 & 0.88155 & 0.00007 & 10.636 & 0.301 \\
L5. & H/5. Gran & 209.5 & 4.2 & 134.7 & 2.7 & 0.79664 & 0.00007 & 4.534 & 0.128 \\
L6. & 11/93. Gran & 222.6 & 4.5 & 88.3 & 1.8 & 0.83973 & 0.00006 & 7.391 & 0.209 \\
P1. & T/5-1. Pel. & 71.7 & 2.1 & 273.0 & 4.6 & 0.75300 & 0.00008 & 0.764 & 0.022 \\
\hline
\end{tabular}

Reference values used in calculations: ${ }^{87} \mathrm{Sr} /{ }^{86} \mathrm{Sr}$ ratios normalised to ${ }^{88} \mathrm{Sr} /{ }^{86} \mathrm{Sr}=8.3752$.

Decay constant $\lambda=1.42 \times 10^{-11} \mathrm{Y}^{-1}$.

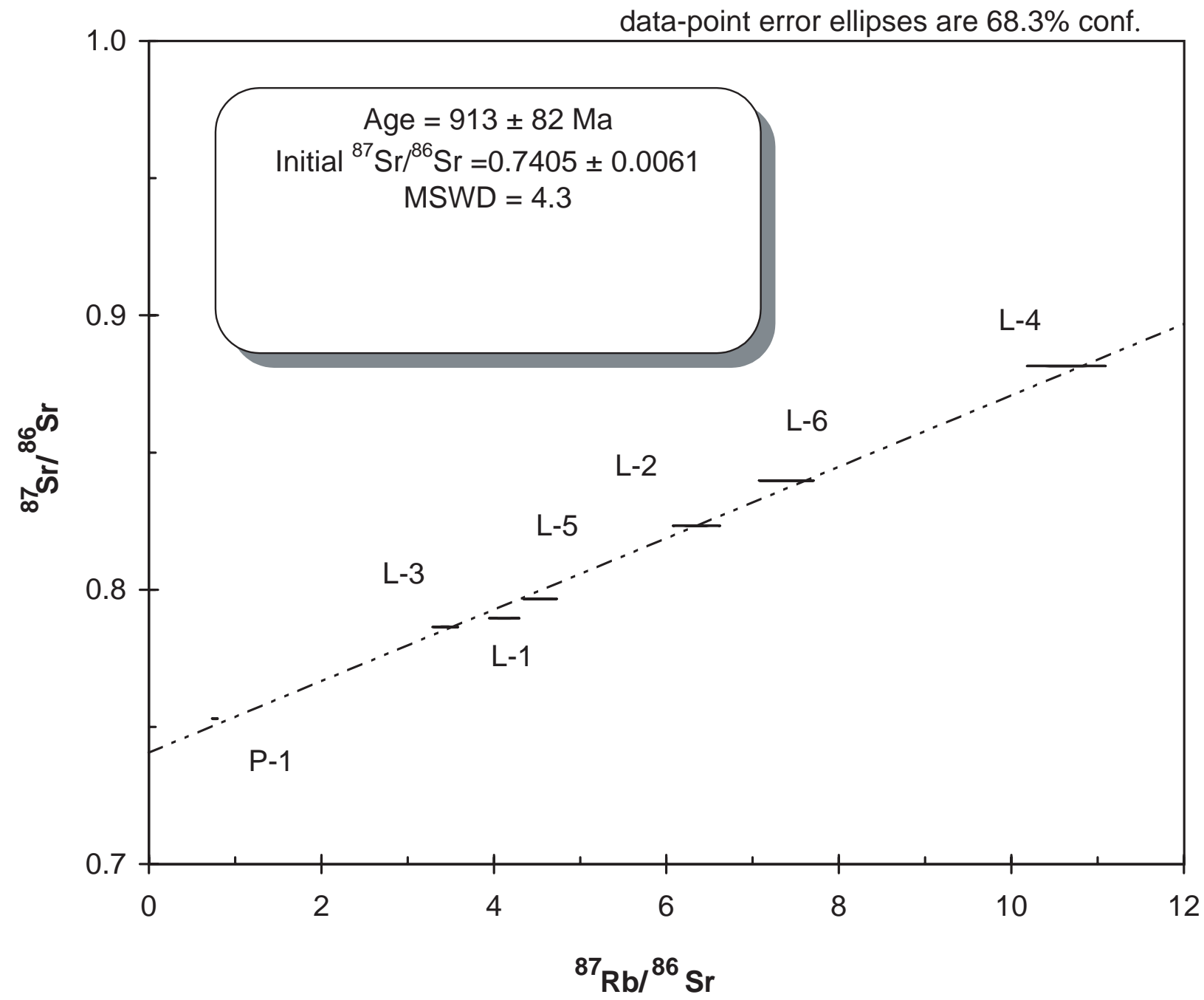

Figure 2. Seven-point Rb-Sr isochron for the granitoid (leptynite) — restite suite of the Chilka Lake area. Data given in table 1.

Table 2. Ion-microprobe data of Zircons of sample 11/93(L-6) leptynite.

\begin{tabular}{c|c|cc|c|c|c|c|c|c}
\hline $\begin{array}{c}\text { Analysis } \\
\text { no. }\end{array}$ & Grain no. & $\begin{array}{c}\text { Measured } \\
{ }^{204} \mathrm{~Pb} /{ }^{206} \mathrm{~Pb}\end{array}{ }^{207} \mathrm{~Pb} /{ }^{206} \mathrm{~Pb}$ & $\begin{array}{c}\text { Total counts } \\
{ }^{206} \mathrm{~Pb}\end{array}$ & $\begin{array}{c}{ }^{206} \mathrm{~Pb} \\
(\mathrm{ppm})\end{array}$ & $\begin{array}{c}{ }^{207} \mathrm{~Pb} /{ }^{206} \mathrm{~Pb} \\
\text { Radiogenic }\end{array}$ & $\begin{array}{c}\text { Error } \\
\text { ratio }\end{array}$ & $\begin{array}{c}\text { Age } \\
(\mathrm{Ma})\end{array}$ \\
\hline 2 & R3g9 & 0.00026 & 0.0762 & 13975 & 66 & 457 & $0.0725 \pm 73$ & 1.02 & $1000 \pm 206$ \\
3 & R6g2 & 0.0003 & 0.0759 & 45150 & 193 & 1375 & $0.0716 \pm 33$ & 1.01 & $975 \pm 95$ \\
\hline
\end{tabular}


Table 3. Ion-microprobe data of Zircons of sample 10/93A (patchy charnockite).

\begin{tabular}{|c|c|c|c|c|c|c|c|c|c|}
\hline $\begin{array}{c}\text { Analysis } \\
\text { no. }\end{array}$ & $\begin{array}{l}\text { Grain } \\
\text { no. }\end{array}$ & $\begin{array}{c}\text { Measured } \\
{ }^{204} \mathrm{~Pb} /{ }^{206} \mathrm{~Pb}\end{array}$ & $\begin{array}{c}\text { Measured } \\
{ }^{207} \mathrm{~Pb} /{ }^{206} \mathrm{~Pb}\end{array}$ & $\begin{array}{l}\text { Total counts } \\
{ }^{206} \mathrm{~Pb}\end{array}$ & $\begin{array}{l}{ }^{206} \mathrm{~Pb} \\
(\mathrm{ppm})\end{array}$ & $\begin{array}{c}\mathrm{U} \\
(\mathrm{ppm})\end{array}$ & $\begin{array}{c}{ }^{207} \mathrm{~Pb} /{ }^{206} \mathrm{~Pb} \\
\text { Radiogenic }\end{array}$ & $\begin{array}{l}\text { Error } \\
\text { ratio }\end{array}$ & Age (Ma) \\
\hline 1 & $\mathrm{R} 2 \mathrm{~g} 1$ & $\mathrm{Nd}$ & 0.0682 & 35530 & 61 & 491 & $0.0681 \pm 22$ & 1.10 & $873 \pm 67$ \\
\hline 2 & R1g3A & $\mathrm{Nd}$ & 0.0689 & 91205 & 169 & 1319 & $0.0689 \pm 1$ & 1.17 & $896 \pm 29$ \\
\hline 3 & R1g3B & $\mathrm{Nd}$ & 0.072 & 20075 & 34 & 242 & $0.0719 \pm 38$ & 1.02 & $984 \pm 107$ \\
\hline 4 & R5g10 & $\mathrm{Nd}$ & 0.1054 & 19270 & 65 & 248 & $0.1054 \pm 39$ & 1.16 & $1722 \pm 68$ \\
\hline 5 & R5g3 & $\mathrm{Nd}$ & 0.1856 & 34685 & 64 & 143 & $0.1846 \pm 24$ & 2.36 & $2694 \pm 22$ \\
\hline 6 & R3g3 & $\mathrm{Nd}$ & 0.0672 & 35775 & 63 & 523 & $0.0672 \pm 22$ & 1.09 & $845 \pm 68$ \\
\hline 7 & $\mathrm{R} 2 \mathrm{~g} 7$ & $\mathrm{Nd}$ & 0.0694 & 17095 & 44 & 338 & $0.0694 \pm 44$ & 0.98 & $911 \pm 132$ \\
\hline 8 & R2g11B & $\mathrm{Nd}$ & 0.0754 & 14380 & 57 & 366 & $0.0753 \pm 52$ & 1.17 & $1078 \pm 139$ \\
\hline 9 & R3g12 & $\mathrm{Nd}$ & 0.0728 & 38435 & 91 & 624 & $0.0728 \pm 21$ & 1.04 & $1008 \pm 57$ \\
\hline
\end{tabular}

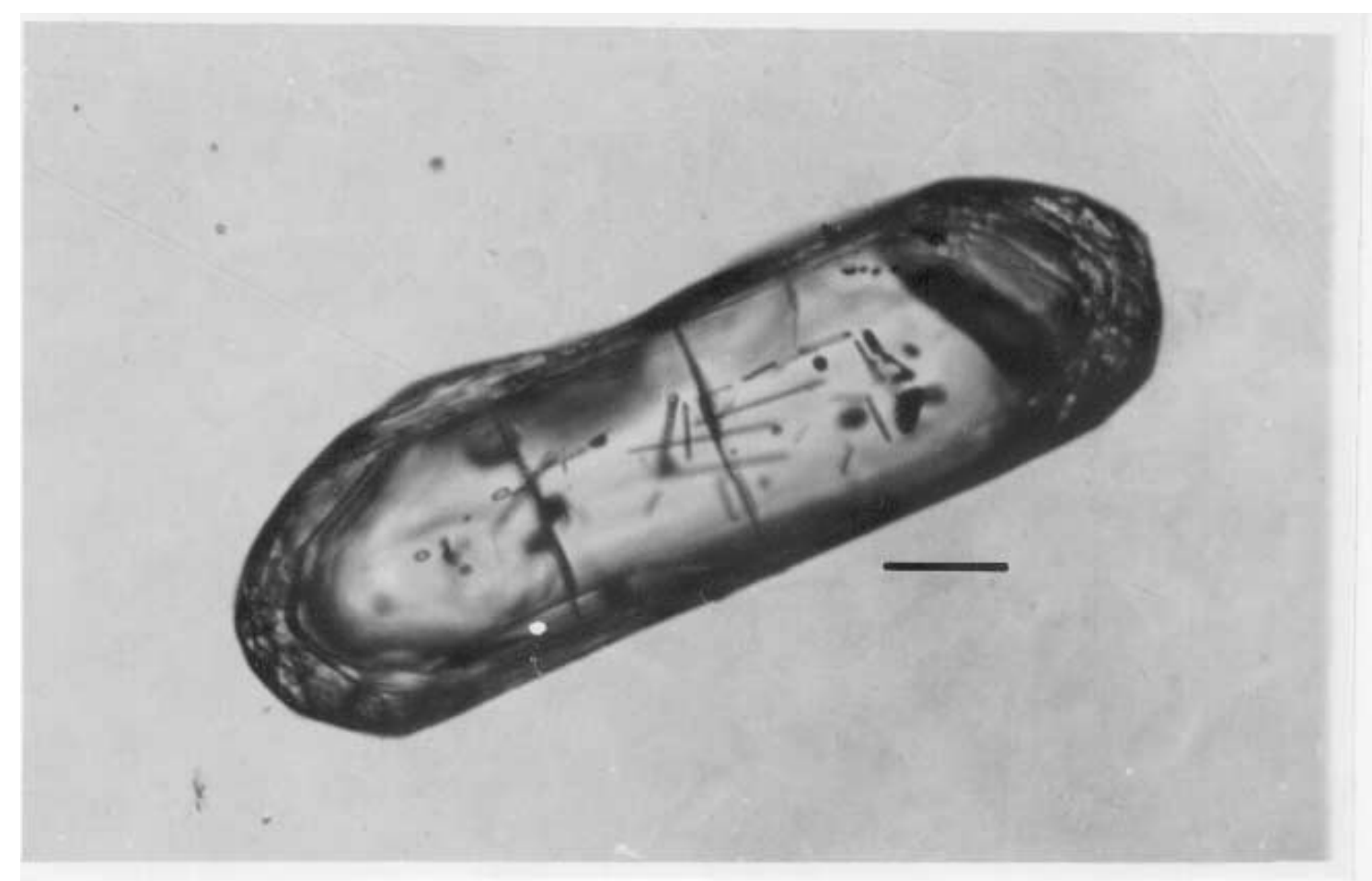

(a)

Figure 3. Transmitted light photomicrographs of representative zircons. Scale bar is $100 \mathrm{~m}$ in each case. (a) Prismatic zircon (r3g9) in leptynite, with homogeneous growth rims.

or subhedral prismatic, colourless and transparent. Most of the grains are homogeneous, with occasional growth rims (figure $3 \mathrm{~b}, \mathrm{c}$ ). In rare cases overgrowths on elongate prismatic core are seen, where growth boundaries are parallel to the margin (figure 3d, e). Seven analysed grains belong to a single population (analysis nos. 1, 2, 3, 6, 7, $8,9)$, give a mean radiogenic ${ }^{207} \mathrm{~Pb} /{ }^{206} \mathrm{~Pb}$ ratio of $0.07051 \pm 0.00028(1 \sigma)$ corresponding to a minimum age of $943 \pm 85 \mathrm{Ma}$. The observed/expected error ratios for most of the analyses vary between 0.98 and 1.17 , indicating that the analysed domains experienced minimum or no $\mathrm{Pb}$ loss. Two analyses (4 and 5) represent older populations. It is important to note that these zircon grains show overgrowth on prismatic core (figure $3 \mathrm{~d}$, e). The analysis number 4 is associated with an error ratio of 1.16 and the radiogenic ${ }^{207} \mathrm{~Pb} /{ }^{206} \mathrm{~Pb}$ ratio of $0.1054 \pm 39$ corresponds to an age of $1722 \pm$ $68 \mathrm{Ma}$. For the grain R5g3 (analysis no. 5) the error ratio is much higher (2.36) indicating $\mathrm{Pb}$ loss. This zircon age $(2694 \pm 22 \mathrm{Ma})$ is not precise, but definitely belongs to an Archaean population.

\section{Discussion}

The overwhelmingly dominant $\mathrm{Pb}-\mathrm{Pb}$ zircon ages around $0.9 \mathrm{Ga}$ from patchy charnockite inclusion and leptynite (peraluminous granitoid) and the $\mathrm{Rb}-\mathrm{Sr}$ whole rock isochron of ca. $0.9 \mathrm{Ga}$ from granitoid-restite suite of the Chilka Lake area imply a strong Grenvillian thermal event in the 


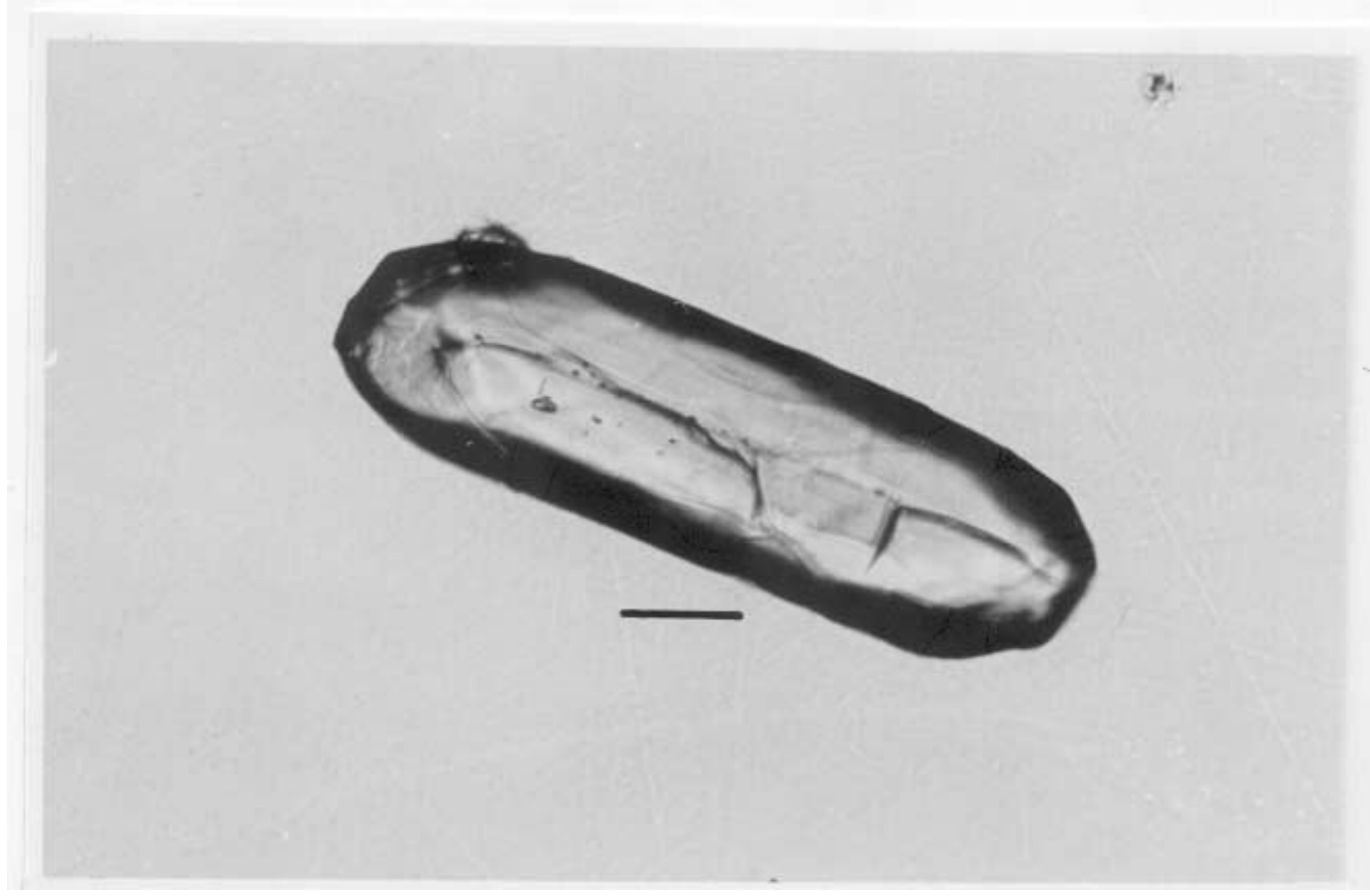

Figure 3(b). Slender prismatic zircon (r2g7) in charnockite, with growth rims.

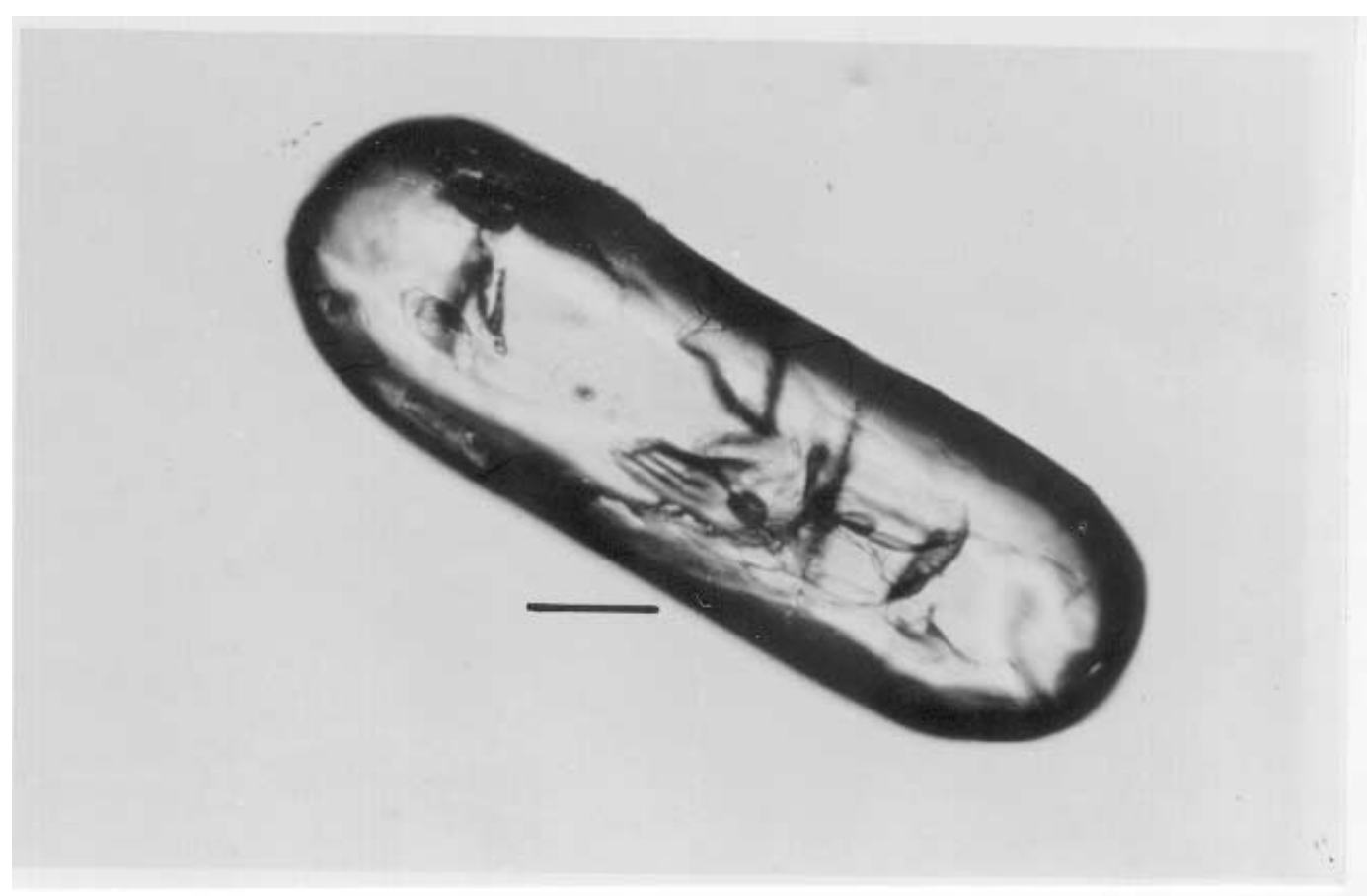

Figure 3(c). Prismatic zircon (r2g11) in charnockite, with rounded terminations.

Eastern Ghats belt. This ca. $0.9 \mathrm{Ga}$ age is interpreted as the age of partial melting of pelitic rocks under granulite facies conditions synkinematic with $F_{2}$ folding, which also resulted in migmatisation of older rocks. Although, a strong Grenvillian thermal event was recorded from several areas in the Eastern Ghats belt, the nature of this thermal event or the tectonic-cum-petrological consequences have not been deciphered so far (Mezger and Cosca 1999).

The $1.7 \mathrm{Ga} \mathrm{Pb}-\mathrm{Pb}$ age of zircon in the charnockite inclusion could represent a previous (pre- $\left.F_{2}\right)$ high-grade event or alternatively charnockitic magmatism. Incidentally, Dobmeier and Raith (2000) 


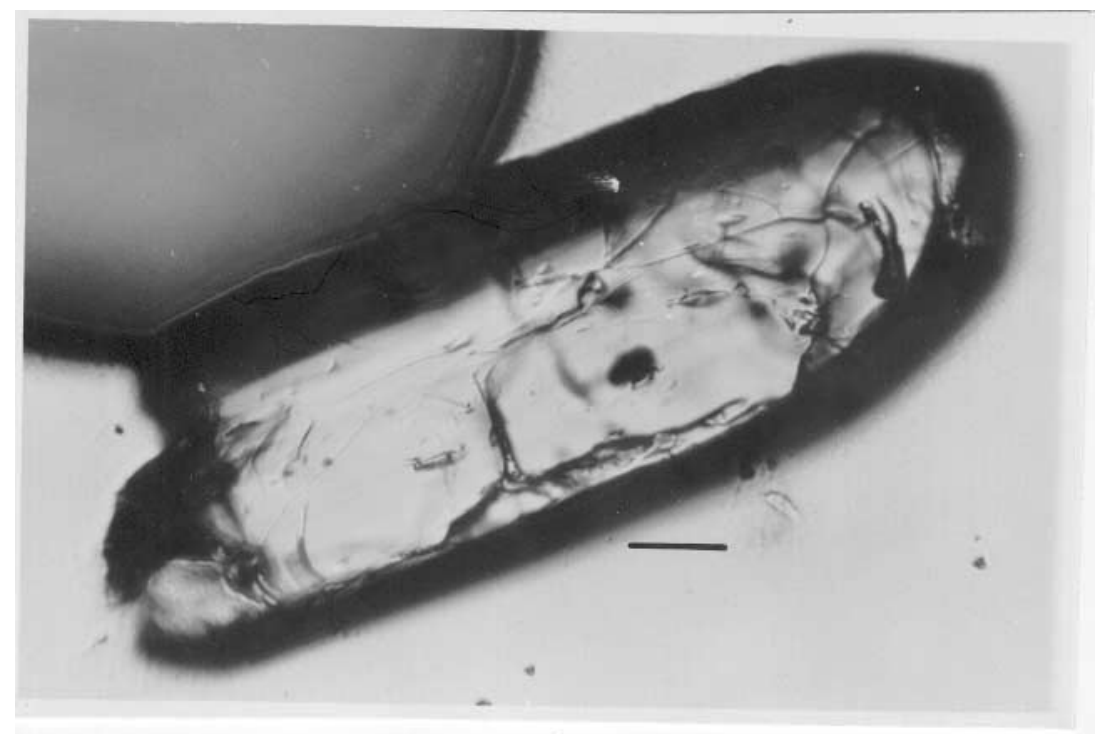

Figure 3(d). Robust prismatic zircon (r5g10) in charnockite, with overgrowth.

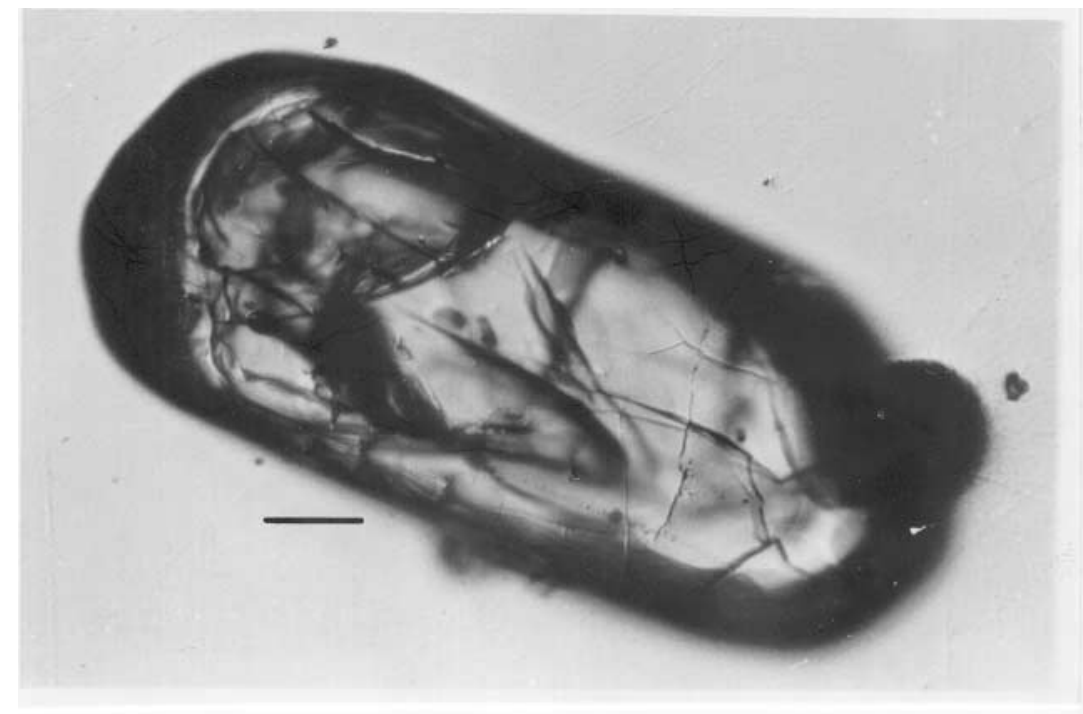

Figure 3(e). Robust prismatic and homogeneous zircon (r5g3) in charnockite.

observed that "since the enderbitic and metasedimentary rocks have identical structural histories, the emplacement (of enderbitic/tonalitic magma) happened prior to the discernible deformation...." in the Chilka Lake area. It is significant that the relatively older status of the patchy charnockites than the host leptynites of the Chilka area was proposed on structural and petrological grounds by Bhattacharya et al 1993 and the isotopic evidence presented in this article confirms the older status of the patchy charnockites of the Chilka area. It is also important to note that from another area (Jenapore, south of Brahmani river, in the northern sector) in the Eastern Ghats belt, Kar (2002), concluded that source rocks of leptynites and patchy charnockites must have been different: leptynites with low $\mathrm{Rb} / \mathrm{Sr}$ ratios $(0.18,0.35)$ from a biotite-bearing source; while patchy charnockites with high $\mathrm{Rb} / \mathrm{Sr}$ ratios $(1.17,1.45)$ from a hornblende-bearing source.

The ca. $2.7 \mathrm{Ga} \mathrm{Pb}-\mathrm{Pb}$ age of zircon from the charnockite inclusion can only represent xenocrystic component. It is noteworthy that $2.6 \mathrm{Ga}$ old zircon was also recovered from metapelite (khondalite) of the Chilka Lake area by Vinogradov et al 1964.

\section{Implications}

In the Eastern Ghats granulite belt some structural and petrological evidence have been advanced 
favoring the hypothesis of reworking: transposition and obliteration of earlier fabrics, and occurrence of older lithological entities as minor inclusions (Bhattacharya et al 1994; Bhattacharya 1997); IBC at two different pressures (Sen et al 1995); post-IBC decompressive path, taken to indicate re-working of an isobarically cooled deep continental crust (Dasgupta and Sengupta 1998). The presence of $1.7 \mathrm{Ga}$ high-grade or magmatic event in the largely Grenvillian partial melting-cummigmatisation event are strong isotopic evidence of reworking, at least in parts of the Eastern Ghats belt.

\section{Acknowledgements}

This work was partly supported by the Brazilian Science Academy in the form of a fellowship to S.B under Inter Academy Exchange Programme. Isotopic work reported here was carried out at the Institute of Geosciences, Sao Paulo University, Brazil and Physical Research Laboratory, Ahmedabad, India. The help and co-operation of the personnel of these laboratories are gratefully acknowledged. Indian Statistical Institute provided the infrastructural facilities. Critical comments and suggestions of an anonymous reviewer are thankfully acknowledged.

\section{References}

Bhattacharya S, Sen S K and Acharyya A 1993 Structural evidence supporting a remnant origin of patchy charnockites in the Chilka Lake area, India; Geol. Mag. $130363-$ 368

Bhattacharya S, Sen S K and Acharyya A 1994 Structural setting of the Chilka Lake granulite-migmatiteanorthosite suite with emphasis on the time relation of charnockites; Precambrian Res. 66 393-409

Bhattacharya S 1996 Eastern Ghats granulite terrain of India: An overview; J. Southeast Asian Earth Science. 14 165-174

Bhattacharya S 1997 Evolution of Eastern Ghats granulite belt of India in a compressional tectonic regime and juxtaposition against iron ore craton of Singhbhum by oblique collision - transpression; Proc. Indian Acad. Sci. (Earth Planet. Sci.) 106 65-75

Bhattacharya S, Kar R, Misra S and Teixeira W 2001 Early Archaean Continental crust in the Eastern Ghats granulite belt, India: Isotopic evidence from a charnockite suite; Geol. Mag. 138 609-618

Chetty T R K and Murthy D S N 1998 Regional tectonic framework of the Eastern Ghats mobile belt: A new interpretation; Geol. Surv. India Special Pub. 44 39-50

Dasgupta S, Sengupta P, Ehl J, Raith M and Bardhan S 1995 Reaction textures in a suite of spinel granulites from the Eastern Ghats belt, India: Evidence for polymetamorphism, a partial petrogenetic grid in the system KFMASH and the roles of $\mathrm{ZnO}$ and $\mathrm{Fe}_{2} \mathrm{O}_{3} ;$ J. Petrol. 36 435-461
Dasgupta S and Sengupta P 1998 Re-working of an isobarically cooled deep continental crust: evidence of decompressive P-T trajectory from the Eastern Ghats belt, India; Indian J. Geol. 70 133-144

Dobmeier C and Raith M 2000 On the origin of 'arrested' charnockitization in the Chilka Lake area, Eastern Ghats Belt, India: a reappraisal; Geol. Mag. 137 27-37

Dobmeier C and Simmat R 2002 Post-Grenvillian transpression in the Chilka Lake area, Eastern Ghats belt - implications for the geological evolution of Peninsular India; Precamb. Res. 113 243-268

Goswami J N and Srinivasan G 1994 Isotopic analysis of early solar system objects by an ion-microprobe: parametric studies and initial results; Proc. Indian Acad. Sci. (Earth and Planet. Sci.) $\mathbf{1 0 3}$ 57-82

Halden N M, Bowes D R and Dash B 1982 Structural evolution of migmatites in a granulite facies terrane: Precambrian crystalline complex of Angul, Orissa, India; R. Soc. Edinburgh 73 109-118

Kamenini D C and Rao A T 1988 Sapphirine granulites from Kakanuru area, Eastern Ghats, India; Am. Mineral. $\mathbf{7 3}$ 692-700

Kar Rajib 2002 Patchy charnockites from Jenapore, Eastern Ghats granulite belt, India: Structural and petrochemical evidences attesting to their relict nature; Proc. Indian Acad. Sci. (Earth Planet. Sci.) $110337-350$

Krause O, Dobmeier C, Raith M and Mezger K 2001 Age of emplacement of massif-type anorthosites in the Eastern Ghats belt, India: constraints from U-Pb zircon dating and structural studies; Precamb. Res. 109 25-38

Lal R K, Ackermand D and Upadhyay H 1987 P-T-X relationships deduced from corona textures in sapphirinespinel-quartz assemblages from Paderu southern India; $J$. Petrol. 28 1139-1168

Mezger K and Cosca M A 1999 The thermal history of the Eastern Ghats belt (India) as revealed by U-Pb and ${ }^{40} \mathrm{Ar} /{ }^{39} \mathrm{Ar}$ dating of metamorphic and magmatic minerals: implications for the SWEAT correlation; Precambrian Res. 94 251-271

Mohan A, Tripathi P and Motoyoshi Y 1997 Reaction history of sapphirine granulites and a decompressional $\mathrm{P}-\mathrm{T}$ path in a granulite complex from the Eastern Ghats; Proc. Indian Acad. Sci. (Earth Planet Sci.) 106 115-130

Paul D K, Ray Barman T, McNaughton N J, Fletcher I R, Potts P J, Ramkrishnan M and Augustine P F 1990 Archaean-Proterozoic evolution of Indian charnockites: isotopic and geochemical evidence from granulites of the Eastern Ghats belt; J. Petrology 98 253-263

Rao A T 1976 Study of apatite-magnetite veins near Kasipatnam, Visakhapatnam district, Andhra Pradesh, India; Tschermaks Min. Petr. Mitt. 2387

Sarkar A, Pati U C, Panda P K, Patra P C, Kundu H K and Ghosh S 1998 Late Archaean charnockitic rocks from the northern marginal zones of the Eastern Ghats belt: a geochronological study; Proc. Int. Seminar on Precambrian crust in eastern and central India. Bhubaneswar, India $128-131$

Sen S K, Bhattacharya S and Acharyya A 1995 A multistage pressure-temperature record in the Chilka Lake granulites: The epitome of metamorphic evolution of Eastern Ghats, India?; J. Metamorphic Geology 13 $287-298$

Sen S K and Bhattacharya S 1997 Dehydration melting of micas in the Chilka Lake khondalites: The link between the metapelites and granitoids; Proc. Indian Acad. Sci. (Earth Planet. Sci.) 106 277-297

Shaw R K, Arima M, Kagami H, Fanning C M, Shivaishi K and Motoyoshi Y 1997 Proterozoic events in 
the Eastern Ghats belt, India: Evidence from Rb-Sr, Sm-Nd systematics and SHRIMP dating; J. Geol. 105 645-656

Shaw R K and Arima M 1998 A corundum-quartz assemblage from the Eastern Ghats Granulite Belt, India: Evidence for high P-T metamorphism? J. Metamorphic Geol. $16189-196$
Vinogradov A, Tugarinov A, Zhykov C, Stapanikova N, Bibikova E and Khorre K 1964 Geochronology of Indian Precambrian; Int. Geol. Congr. Rep. 22nd session; 10 553-567.

Wiedenbeck M and Goswami J N 1994 High precision ${ }^{207} \mathrm{~Pb} /{ }^{206} \mathrm{~Pb}$ zircon geochronology using a small ion microprobe; Geochem. Cosmochem. Acta. 58 2135-2141 